\title{
SNCG wt Allele
}

National Cancer Institute

\section{Source}

National Cancer Institute. SNCG wt Allele. NCI Thesaurus. Code C50976.

Human SNCG wild-type allele is located within10q23.2-q23.3 and is approximately $13 \mathrm{~kb}$ in length. This allele, which encodes gamma-synuclein protein, plays a role in the modulation of axonal architecture and neurofilament integ rity. This gene is highly expessed in advanced breast carcinomas, suggesting a correlation between SNCG overexpression and breast tumor development. 